\title{
N-エチルマレイミド処理グルテンの物性に及ぼす 凍結および凍結乾燥の効果
}

\author{
吉田千秋*・矢埜みどり*・団野源一**
}

\author{
Effect of Freezing and Lyophilization on Rheological \\ Properties of Gluten treated with N-Ethylmaleimide
}

\author{
Chiaki YoshidA*, Midori YANO* and Gen-ichi DanNo** \\ * Kyoto Junior College, 3370, Hori, Fukuchiyama-shi, Kyoto 620 \\ ** Department of Agricultural Chemistry, Kobe University, \\ 1-1, Rokkodai-cho, Nada-ku, Kobe-shi, Hyogo 657
}

\begin{abstract}
The effects of lyophilization on the rheological properties of gluten prepared from wheat flour by washing with or without $N$-ethylmaleimide (NEMI) were studied. The extensibility of the gluten prepared with NEMI (NEMI-gluten) decreased by lyophilization, but recovered in the presence of cysteine. These phenomena were more noticeable on the gluten prepared without NEMI (control-gluten). The lyophilization or freezing of control-gluten caused the formation of larger amount of SDS-insoluble fraction than NEMI-gluten. The SDS-insoluble fraction will be high molecular weight aggregate containing intermolecular disulfide bonds, as the fraction was solubilized with 2mercaptoethanol. Gel filtration chromatography on Sepharose $4 \mathrm{~B}$ and a viscosity measurement showed that high molecular weight gluten of NEMI-gluten remained in SDS-soluble fraction because of suppression of the formation of an aggregate. These results suggested that the disulfide polymer of gluten proteins formed during lyophilization will be responsible for the decrease in the extensibility of gluten.

(Received Aug. 18, 1995)
\end{abstract}

製パン過程においてドウを凍結するとパン容積の減少 することが知られている.この原因として醉母の活性低 下が考えられてきたが最近, ドゥの構造変化(1)2), および ドウ強度の減少勇4)によると報告されている。また， DREESE ら5) は東結乾燥グルテンは加熱処理したグルテ ンに比へ弾性が增加し粘性が低下することを報告してい るかその理由については明らかにされていない。一方, PRESTON ら ${ }^{6)}$ は酸不溶性グルテンを小麦粉に添加する とドウの弾性が增加し粘性が減少すること、およびパン 容積が低下することを報告している．以上のことから東 結および東結乾燥中におこるドゥの物性変化はグルテン タンパク質の SS 重合によると考えられるので，N-エチ ルマレイミト (NEMI) で SH 基を修飾したクルテンを
調製して凍結および凍結乾燥に伴う物性変化とグルテン タンパク質の分子量变化との関連性について検討した.

\section{実 酸 方法}

1. 試 料

日清製粉の $1 \mathrm{CW} \mathrm{n}$-ブタノール, ついで $\mathrm{n}$-へキサ ンで脱脂したすのを使用した.

\section{NEMI 処理グルテンの調菿}

本実験では混ねつに伴う相互作用を避けるため以下の 方法でグルテンを調製した. 小麦粉 $100 \mathrm{~g} に 0.5 \mathrm{~g}$ の $\mathrm{NEMI}$ を含む水 $1000 \mathrm{~m} l$ を加えて 30 分間おだやかに措 抖した後 $3000 \mathrm{rpm}$ で 3 分間遠心した. 得られた沈激を $1000 \mathrm{ml}$ の水に分散して洗浄後, 残查をメッシュに移し

*京都短期大学 (テ620 京都府福知山市字城 3370)

** 神戸大学農学部（テ657 兵庫県神戸市六甲台町 1-1) 
流水中でデンプンを除いて湿グルテンを集めた。 これを NEMI グルテンとして実験に供した. NEMI 処理しない グルテンあ同様に調製し対照グルテンとした。

\section{3. 凍結および凍結乾蝶グルテンの調筡}


カ月間倲結して実験に供した。凍結乾燥グルテンは湿グ ルテン $10 \mathrm{~g}$ を $2 \mathrm{~g}$ ずつに分割してドライアイスーアセト ンで直ちに凍結後涷結乾燥した，乾燥後，乳鉢内ですり

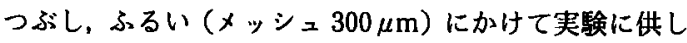
た.

\section{4. グルテンタンパク質の分画}

タンパク質の分画はDANNO と HOSENEY の方法7に 従って行った. すなわち, 湿グルテン $2.5 \mathrm{~g}$ に $2 \mathrm{~g}$ のラウ リル硫酸ナトリゥム（SDS）を加えて混和し，ついで $0.01 \mathrm{M}$ トリス一塩酸緩衝液, $\mathrm{pH} 8.0$ を $35 \mathrm{ml}$ 加えて攪 拌して溶功した後 $12000 \mathrm{rpm}$ で 30 分遠心した。 得られ た不溶性画分をSDS 不溶性画分とした. 凍結乾燥グル テンより SDS 不溶性画分の調製はグルテン $1 \mathrm{~g} に 1.6 \mathrm{~g}$ の SDS を加えて混和しトリス一塩酸緩衙液 $20 \mathrm{~m} l$ を加え て同様に行った．タンパク質定量はミクロケルダール法 （N×5.7）で行った.

5. セファロース4Bカラムクロマトクラフィー

グルテンタンパク質の分子量分布は $0.2 \%$ SDS を含む $0.01 \mathrm{M} ト$ リス一塩酸紘衝液， $\mathrm{pH} 8.0$ で平衡化したカラム $(2.5 \times 34 \mathrm{~cm})$ で分析した.

\section{6. 物性テスト}

グルテンの伸張性は前報8 に従って測定した.

\section{7. 粘度測定}

粘度の測定は Cannon-Fenske 粘度計を用いて $30^{\circ} \mathrm{C}$ で行った。

\section{SH 基の定量}

SH 基は KARUSH ら9)の方法に従って定量した。

\section{実験結果および考察}

湿グルテンの引っ張り試験を行ない，伸張抵抗が最大 となる時の伸びの大きさを測定した，Fig. 1 に示すよう にNEMI グルテンは対照グルテンより伸びが大きく伸 張性に優れていた，両グルテン共システィンの添加に よって伸張性が增加した．NEMI グルテンを凍結乾燥す ると伸張性は低下するがシステインの添加により回復し た。対照グルテンは棟結乾燥により伸張性はさらに低下 するがシステインの添加によりほぼ完全に回復した。

グルテンは凍結乾燥により粘性が低下し弾性が增加す ることが DREESE ${ }^{5)}$ により辄告されているがその原因に
A
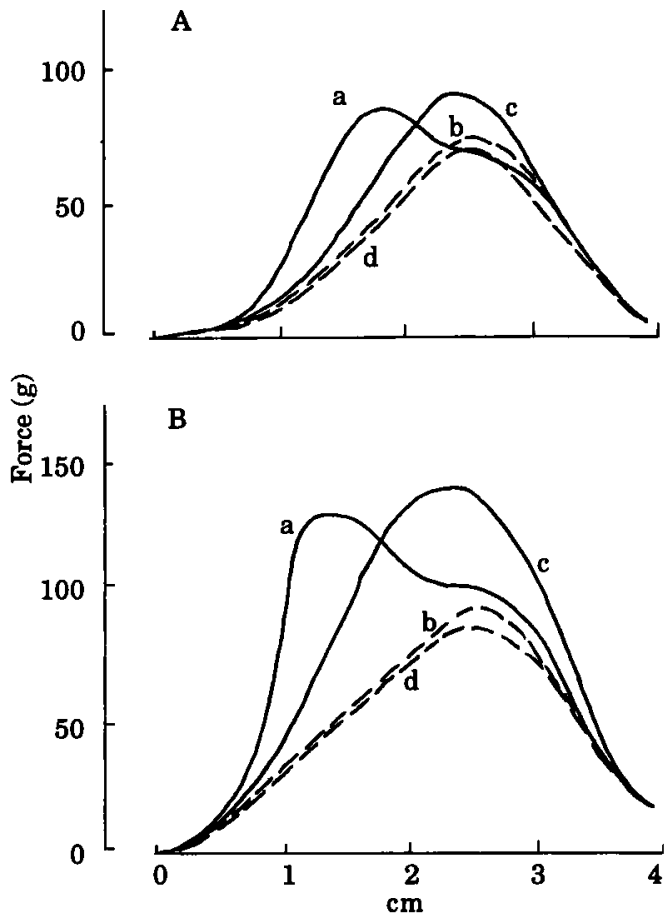

Fig. 1 The extensibility of wet (A) and lyophilized (B) gluten

Wet gluten $(1.5 \mathrm{~g})$ or lyophilized gluten $(1 \mathrm{~g})$ was mixed with water or water containing $0.5 \mathrm{mg}$ of cysteine, and molded into a rectangle of $3 \mathrm{~mm}$ thickness (cross section, 0.3 $\mathrm{cm}^{2}$ ). The measurement was performed with a Tensipresser (Taketomo Inc.) with a hook of $5 \mathrm{~mm}$ diameter. a, control-gluten; $b$, control-gluten +cysteine ; c, NEMI-gluten ; d, NEMI-gluten + cysteine.

ついては明らかにされていない，以上のようなグルテン の伸張性の変化はグルテンタンパクのSS 重合之関連性 があると考えられるのでグルテンのタンバク分画を行っ た. その結果は Table 1 に示すように湿対照グルテンは NEMI グルテンにくらべて SDS 不溶性画分が多く，東 結乾燥するとさらに增加した. この画分は 2-メルカプト エタノールで可溶化したことからSS 結合による重合物 と考えられる.したがって，凍結乾燥した対照グルテン がシステイシ添加で伸張性が著しく增加したのは生成し たSDS 不溶性画分がシステインで㯰元されて低分子化 されたためと考えられる．また，対照グルテンは東結に よっても SDS 不溶性画分が $38 \%$ に增加したが NEMI 
グルテンでは $12 \%$ であった.

SDS 不溶性画分はグルテンタンパク質が凍結および 凍結乾燥中に SS 重合したものと示唆される結果が得ら れたので浽グルテンのSH 基の定量をおこなった。

Table 2 に示すように NEMI グルテンの SDS 可溶性画 分の SH 基は対照グルテンの約 5 分の 1 に減少した。両 グルテン共, 凍結および倲結乾燥しても SDS 可溶性画 分のタンパク当たりのSH 含量はほとんど変化がなかっ た.これは SS 重合により生じた SDS 不溶性画分が除か れたためと考えられる。 また，不溶性画分は 2-メルカプ トエタノールで可溶化するこよからも凍結および凍結乾 燥により SS 重合体が生成されるあのと考えられる。 ま た，後述のゲルロ過で得られた NEMI グルテンの高分 子区分す减少するがわずかに未修飾の $\mathrm{SH}$ 基が認められ た. 凍結による SDS 不溶性画分が対照グルテンの $38 \%$ に対してNEMI グルテンでは $12 \%$ と少ないのは, NEMIによりグルテンタンパク質の SH 基が修飾され SS 重合の形成が抑えられたためと考えられる.NEMI

Table 1 SDS-insoluble fraction of gluten

\begin{tabular}{lcc}
\hline \hline & Control-gluten & NEMI-gluten \\
\hline Wet & $20 \%$ & $8 \%$ \\
Frozen & 38 & 12 \\
Lyophilized & 46 & 37 \\
\hline
\end{tabular}

SDS-insoluble fraction was dissolved in $2 \%$ of 2-mercaptoethanol and the protein content was assayed with the Kjeldahl method.

Table 2 SH groups in SDS-soluble fractions

\begin{tabular}{lcc}
\hline \hline & $\begin{array}{c}\text { Control-gluten NEMI-gluten } \\
\text { (SH moles/10 } \mathrm{g} \text { ) }\end{array}$ \\
\hline SDS-soluble fraction & & \\
wet & 26.0 & 5.4 \\
frozen & 25.5 & 5.3 \\
$\quad$ lyophilized & 24.3 & 5.5 \\
Sepharose 4 B & & \\
chromatography & & \\
$\quad$ Peak I & 7.4 & 0.7 \\
$\quad$ Peak II & 12.3 & 2.1 \\
\hline
\end{tabular}

SH contents of SDS-soluble fraction and the peaks from gel filtration indicated by arrows were determined by the method of KARUSH et al.
グルテンでも凍結により SDS 不溶性画分が増加するの は末修飾の SH 基が存在することによる，凍結乾燥によ り不溶性画分がさらに増加するのは凍結乾燥過程中, グ ルテン塊内に部分的な非凍結や濃縮が生じ SS 重合が促 進されたのものと考えられる.

次に凍結によるSDS 可溶性画分の分子量分布の変化 をセフアロース4 B を用いるゲルロ過で調べた，溶出パ ターンは Fig. 2 に示すようにピーク I，ピーク IIおよび 中間区分からなりそ机そ嚆分子グルテニン，グリアジ ンおよび低分子グルテニンである. 湿対照グルテンは湿 NEMI グルテンより全タンパクに対するピーク I（高分 子グルテニン）の比率が低い.これは湿対照グルテンに 存在するSDS 不溶性画分（20\%）が湿 NEMI グルテン のそれ (8\%) より多いので対照グルテンの SDS 可溶性 画分に存在する高分子グルテニンが NEMI グルテンよ り少ないためである.

また，対照グルテンを凍結すると湿グルテンより高分 子区分の比率が低くなるが，これは東結により生じた SDS 不溶性画分 (18\%) が除かれるためである。一方, NEMI グルテンでは凍結してあ生じた SDS 不溶性画分

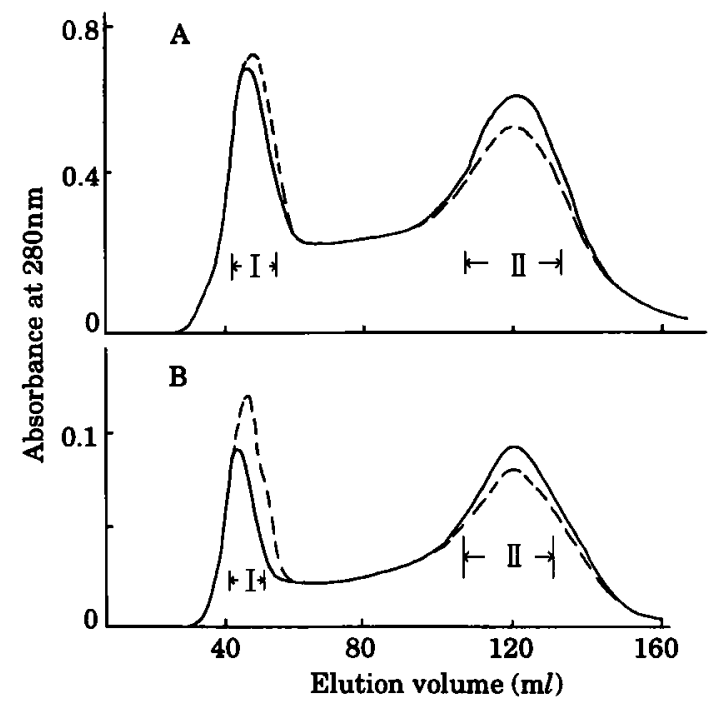

Fig. 2 Gel filtration of SDS-soluble fraction of wet (A) and frozen (B) gluten on a Sepharose 4 B column $(2.5 \times 34 \mathrm{~cm})$ SDS-soluble fraction $(5 \mathrm{ml})$ of wet gluten (10 $\mathrm{mg} / \mathrm{m} l)$ or of frozen gluten $(1.2 \mathrm{mg} / \mathrm{ml})$ was applied on the column. - control-gluten ; ----, NEMI-gluten. 
Table 3 Relative viscosities of SDS-soluble fractions

\begin{tabular}{lcc}
\hline \hline & Control-gluten & NEMI-gluten \\
\hline Wet & 1.36 & 1.38 \\
Frozen & 1.35 & 1.52 \\
\hline
\end{tabular}

Protein concentration; $0.25 \%$, Solvent ; $0.01 \mathrm{M}$

Tris- $\mathrm{HCl}$ buffer, $\mathrm{pH} 8.0$ containing $0.2 \%$ SDS.

（4\%）はわずかなので東結前後でこの比率はほとんど変 わらなかった． 凍結した NEMI グルテンの SDS 可溶性 画分は湿 NEMI グルテンのそれより低湦度でも粘調性 が高く，溶出パターンにみられるようにピークIは遅れ て溶出された，遅れて溶出されるのは低分子化によるす のでなく倲結により粘度が增加したものであることを相 対粘度測定で確かめた。 Table 3 に示すように NEMI グ ルテンは凍結で SDS 不溶性画分がわずかながら除かれ るにもかかわらず相対粘度は增加した.

また，対照グルテンはSDS 不溶性画分が 18\% 除かれ るが相対粘度はほとんど低下しなかった．凍結により相 対粘度が高くなるのはSDS 可溶性画分中に分子間 SS 結合をふくむ高分子集合体が形成されることが考えられ る. 対照グルテンでは高度の分子間 SS 結合が形成され るため集合体は不溶化するので相対粘度は高くならない が, NEMI グルテンではグルテンタンパク質の SH 基が 少ないため不溶化しにくく，粘性の高い高分子集合体が SDS 可溶性画分に残るあのと考えられる. 以上の上うに 凍結乾燥によりグルテンの SDS 不溶性画分が増加する ことからグルテンタンパク質の SS 重合体が形成され, そのためグルテンの伸張性が低下するすのと考えられ る.

小麦粉の混如つ時に NEMIを加えるとドウが著しく 軟化することおよびグルテンタンパク質の抽出性の増加 することが知られているが，これらはグルテニンの低分 子化によると説明されている(10)11).今回, 混ねつせずに 調製した NEMI グルテンの粘度は対照グルテンと変わ らないので, NEMI 存在であ低分子化は起こっていない と思われる. また, 混ねつなしであ SDS 可溶性画分は増 加するがこれは低分子化に伴う溶解性の增加ではなく SS 重合による不溶化が揤えられたためと考えられる.

小麦㸮を䣫酸で抽出したとき残査中に残る，いわゆる 酸不溶性タンパク質 ${ }^{12)}$ は抽出方法や使用する溶媒に よって残存量が異なる ${ }^{13)}$ ，本研究におけるSDS 不溶性 画分はこのような可溶化以前のグルテンの存在状態をあ
らわすすのではなく凍結および凍結乾燥により不溶化し たグルテンである．湿ねつにおいて NEMI はグルテニ ンの SH 基を修飾することによりグルテニンの重合を抑 えることが報告されている゙4). 混ねつ中, グルテンタン パク質の可溶化と並行して SS 重合によるグルテンタン パク質の不溶化が起こりその量比がグルテンの物性に大 きな影蓈を与えると考えられる。

小麦粉に酸不溶性タンパクを添加するとパン容積が低 下することが報告されている6).グルテンを冷凍保存す ると製パン性が低下するが，保存中に生成する難溶性の 高分子タンパクが関係するすのと思われる，製パンにお いて小麦粉にバイタルグルテンが添加されるがタンパク 量の強化とともに全タンパクに対する難溶性の高分子夕 ンパク質の此率も製パン性改良の要因であろう.

\section{要 約}

小麦粉を水で瑟濁して得たグルテン（対照グルテン） および NEMI 処理したグルテン（NEMI グルテン）の凍 結および凍結乾燥にともなう物性変化を調べた。両グル テン共, 凍結乾嬠すると伸張性は低下し, システィンの 添加により回復するが, 低下および回復の程度は対炤グ ルテンの方が著しかった. 凍結乾燥または凍結により SDS 不溶性画分が増加するが対照グルテンの方が多 かった. SDS 不溶性画分は分子間 SS 結合による高分子 重合体であるが, NEMI グルテンは凍結してもSDS不 溶性画分の生成はわずかであった. しかし，NEMI グル テンの SDS 可溶性画分は高分子グルテンタンパク質が 增加するため高粘調性を示した.これらのことより東結 および倲結乾燥によりグルテンタンパク質の SS 重合体 が形成されるためグルテンの伸張性が低下すると考えら れる.

\section{文献}

1) Berglund, P.T., Shelton, D.R. and Freeman, T. P. : Cereal Chem., 67, 139 (1990).

2) Berglund, P.T., Shelton, D.R. and Freeman, T. P. : Cereal Chem., 68, 105 (1991).

3) Inoue, Y. and Bushuk, W. : Cereal Chem., 68, 627 (1991).

4) Inoue, Y. and Bushuk, W. : Cereal Chem., 69, 423 (1992).

5) DReese, F.C., F Aubion, J.M. and Hoseney, R.C. : Cereal Chem., 65, 354 (1988).

6) Preston, K.R. and TipPles, K.H. : Cereal Chem., 57, 314 (1980).

7) Danno, G. and Hoseney, R.C. : Cereal Chem., 59, 
249 (1982).

8) Karush, F., Klinman, N.R. and Markes, R. Annal. Biochem., 9, 100 (1964).

9) Yoshida, C. and Danno, G. : Agric. Biol. Chem., 53, 121 (1989).

10) Meredith, P. and Bushuk, W. : Cereal Chem., 39, 411 (1962).

11) Tanaka, K. and Bushuk, W. : Cereal Chem., 50,
590 (1978).

12) ORTh, R.A. and Bushuk, W. : Cereal Chem., 49, 268 (1972).

13) Chakraborty, K. and Khan, K. : Cereal Chem., 65, 333 (1988).

14) Danno, G., Xu, S.R. and Natake, M.: Agric. Biol. Chem., 54, 985 (1990).

(平成 7 年 8 月 18 日受理) 